\title{
Entrepreneurship Education and Graduate Unemployment in Kogi State
}

\author{
Grace Gift Rotimi, Dare Joseph Enimola*, Zekeri Ochidi \\ Department of Business Administration, Kogi State University, Anyigba, P.M.B. 1008, Nigeria \\ e-mail: darejosephenimola@gmail.com
}

DOI: 10.51865/EITC.2021.03.06

\begin{abstract}
The study aimed at the inclusion of entrepreneurship in the education curriculum and the inability of graduates to get jobs in Kogi State. Thus entrepreneurship education and its impact on graduate unemployment were investigated. A descriptive survey design was used to achieve the study's objectives. Six (6) higher institutions in Kogi State were chosen to make up the study's population. Due to the nature of the research, we concentrated on students. The study determined the sample size of 385. Inferential and descriptive statistics were used to analyze the data gathered. Multiple regression analysis (inferential statistics) was applied to unveil the impact of independent variables on the dependent variable. The finding showed that entrepreneurship education has a significant effect on the unemployment rate of graduates in Kogi state. The study concluded that entrepreneurship in the education curriculum can influence a reduction in the unemployment rate of graduates in Kogi State. The study recommended the review of policy relative to entrepreneurial education to enhance the high degree of its effectiveness in Kogi State higher institutions.
\end{abstract}

Keywords: entrepreneurship education; entrepreneurship curriculum; graduate unemployment; entrepreneurial culture; creativity.

JEL Classification: L26; P36; E24.

\section{Introduction}

For a long time now, the Nigerian Government has focused on entrepreneurship (in her strategic plan) to systematically combat the growing rate of unemployment and poverty. The statistics on the unemployment rate in Nigeria show that people who graduated from higher institutions have not been able to get any job (white-collar or blue-collar jobs) (Adiak and Katura, 2014). This is a serious social and economic problem. Unemployed graduates may result in social crimes and injustice with a long frustrating period of joblessness. They are possibly going to be unproductive and redundant with a gradual decay in the knowledge and skills acquired, which could have contributed to the economic growth of the nation. It is traumatic for graduates who invested their time and other resources way back at school with the optimism that jobs will be available upon their graduation. Despite the country's owned mineral and natural resources (that include crude oil, coal, natural waters, and land for agriculture), graduates spend money and

${ }^{*}$ Corresponding author 
assert intensive effort looking for jobs (Ogwu, Omeje, \& Nwokenna, 2014). Relatively speaking, such problems are due to the current state of the 'Nigerian educational system', which has a fundamental discrepancy between the curriculum framework and the pressures of the twenty-first century.

According to Global Entrepreneurship Monitor (GEM) 2019 report on entrepreneurial in ten sub- Saharan African Countries, the entrepreneurship level in Nigeria stood at $44 \%$ which is comparatively low as a giant of Africa when considering other countries like Uganda with $79 \%$, Botswana with $72 \%$, Angola with $70 \%$ and Malawi with 70\%. Also, Global Entrepreneurship Index (GEI) report, ranks Nigeria 101st out of 137th countries and 12th in Africa with (20\%) entrepreneurship level despite the introduction of University Entrepreneurship Education (UEE) in 2006 and the recent policy to illuminate business operations. Other African countries like Tunisia have the highest GEI ranking with $42.4 \%$, Botswana 35\%, South Africa 33\%, Namibia $31 \%$, Morocco 29\%, Egypt 26\%, and Gabon 25\%. Furthermore, Nigeria is bedeviled with increasing graduation of students who will fall into the bracket of unemployed people. Around 5.2 million Nigerian university graduates are reportedly unemployed (Longe, 2017). Every year 2.2 million students pass out of higher institutions (National Bureau of Statistics, 2019). Nigerian graduates who study abroad usually come back home and compete for the few available jobs (Sania \& Jamilb, 2020). Unemployment has always been a pitiful problem in African countries, causing not only economic disruption but also a barrier to the fulfillment of dreams. In Nigeria, unemployment is regarded as a serious problem that needs the government's immediate, consistent, and long-term attention (Bakar, Islam \& Lee, 2015).

There is no doubt that entrepreneurship education will foster a reduction in unemployment in Nigeria. Entrepreneurship education aims to adequately equip students of tertiary institutions with entrepreneurial competencies and skills necessary for a successful business venture before graduation. The attainment of the objectives will require diligent instructional delivery and regular monitoring since the fact remains that the implementation status of any academic content is the major factor that determines its effectiveness. Despite the introduction of entrepreneurial education in tertiary institutions to inculcate attitudes, values, psychological mindsets, and strategies necessary for the subsequent take-off venture among the university graduates, the rate at which it fosters the attitude of graduates towards considering entrepreneurship for self-reliance is not encouraging. The unemployment rate among graduates is increasing (Sania \& Jamilb, 2020).

However, despite the government efforts to inculcate entrepreneurship in the education curriculum), there is a lackadaisical attitude of youth graduates towards a preference for fixed salary jobs as opposed to self-employment. The mindset has triggered several social and economic problems in the country, like kidnapping, insurgency, irregular migration, militancy, generalize violence, to mention but a few. In this regard, this study deemed it fit to look inward on how entrepreneurship education can curb graduate unemployment in Nigeria looking at parameters such as entrepreneurial creative skills, entrepreneurial teaching methods, entrepreneurial risk-taking, entrepreneurial career aspiration, and entrepreneurial culture and their impact on graduate unemployment within the Nigeria context.

\section{Literature Review}

\section{Entrepreneurship education}

Entrepreneurship education is the guidance provided to groups or individuals to help them improve their natural entrepreneurial abilities and gain the expertise, abilities, behaviors, and values required to begin successful business enterprises in their immediate environment and make a decent living. In his description, Osuala (2004) established entrepreneurship education as "specialized training provided to students for them to learn skills, ideas, and management 
expertise needed for self-reliance." While entrepreneurship is the act of taking on risk in a business enterprise, entrepreneurship education can provide students with the requisite competencies, techniques, and understanding to take on risk in a new business. This is to promote self-employment so that they can have a more stable and meaningful life upon graduation.

Okolocha and Ile (2011) opined that entrepreneurship education is an educational program designed to prepare young people to acquire appropriate business skills, business ideology, knowledge, and ability that will help them live a suitable life, improve their financial position and promote the growth of the nation. Entrepreneurship education aims to equip graduates with entrepreneurial skills that will allow them to become self-sufficient as well as more employable and make a significant contribution to their country's economic growth. From Nnamdi's (2010) point of view, entrepreneurship education reflects learning the necessary skills that will enhance taking entrepreneurial risks without fear, and running a new business successfully. According to Nwankwo, Nwachukwu, and Chinedu (2010), entrepreneurship education is based on the development of entrepreneurial competencies as a revived means of achieving self-reliance. Support services from the government, individuals, and businesses are critical to achieving prosperity and achieving the stated goal.

\section{Graduate unemployment}

Unemployment is an issue that traumatizes graduates in Nigeria. The consequences of unemployment fall on both the individual and the nation. It contributes to the poverty level of individuals and reduces their social status. It has a dire consequence on the economic and social progress of the nation. The high level of insecurity and an increasing number of intelligent terrorists may be accounted for by the unemployment rate in Nigeria.

For this study, unemployment is seen as the situation whereby several graduates (who are mentally and physically fit and are seeking job opportunities under the prevailing condition of service) could not find a paid job. In a related development, Gbosi (2006) refers to unemployment as pathetic conditions of graduates who are capable and willing to work considering a given wage rate cannot get a job. Graduate refers to individuals with any form of post matriculation qualification or tertiary diploma or certificate (Paum, Oosthuizen \& Van Der Westhuizen, 2008) in Bassey and Atan (2012). Graduate unemployment is seen as a circumstance in which people with any type of post-enrollment qualifications are physically and mentally prepared to work at any given rate of wages and other conditions of service but have not been able to find a job. Graduate unemployment according to Salihu, Muhammed, and Bayero (2016) is a global phenomenon whereby the eligible workforce of the state is deprived of the service to the country. The only difference lies in the magnitude and the rate of unemployment which is unevenly distributed among countries. This is not only a serious economic issue but also has implications that affect almost all countries (Nigeria inclusive) and all people either directly or indirectly. Unemployment (especially among graduates) causes social unrest and increased crime, continuing youth unrest, and an unstable socio-economic configuration. According to Ajufo (2013), youth unemployment has national and international implications.

Most of those who engaged themselves in these forms of sophisticated crimes have some sort of formal education and training and since the government is unable to judiciously utilize their talents, they look for ways to illegally use these talents. Desperation according to Ajufo (2013) can drive many people into living outside the law to survive and a means of expressing dissatisfaction at the apparent neglect of their very existence. The issue of graduate unemployment according to Ajayi, Adeniji \& Adu (2008) has caught the attention of policymakers, parents, educationists as well as media commentators. The situation is almost certainly worse than expected as over 2.5 million graduates from the nation's Tertiary Institutions are presently wandering around looking for unavailable employment. Agi and 
Arikawei (2011) stated that more than 200,000 graduates are supplied to the Nigerian Labour Market each year, but only 25 percent is often absorbed. The remaining $75 \%$ are left in the labour market perpetually looking for jobs.

\section{Methodology}

\section{Research design}

A descriptive survey was also adopted by the researchers because it sought the opinions of respondents on the status of entrepreneurship education in Kogi State tertiary institutions.

\section{The population of the study}

The research population comprises six (6) higher institutions in Kogi State. Our focus was on the students going by the nature of the study.

Table 1. Population frame

\begin{tabular}{|l|l|c|c|c|}
\hline S/N & \multicolumn{1}{|c|}{ Institutions } & $\begin{array}{c}\text { Number of } \\
\text { male students }\end{array}$ & $\begin{array}{c}\text { Number of } \\
\text { female } \\
\text { students }\end{array}$ & $\begin{array}{c}\text { Total number } \\
\text { of students }\end{array}$ \\
\hline 1. & Kogi State University, Anyigba & 745 & 946 & 1691 \\
\hline 2. & Federal College of Education Okene & 1124 & 826 & 1950 \\
\hline 3. & Federal Polytechnic Idah & 653 & 491 & 1144 \\
\hline 4. & Federal University, Lokoja & 350 & 405 & 755 \\
\hline 5. & Kogi State Polytechnic, Lokoja. & 1169 & 987 & 2156 \\
\hline 6. & $\begin{array}{l}\text { Kogi State College of Education } \\
\text { Ankpa }\end{array}$ & 1574 & 1100 & 2674 \\
\hline & TOTAL & & $\mathbf{1 0 , 3 7 0}$ \\
\hline
\end{tabular}

Source: Authors’ Field Survey, 2020.

\section{Sample size and sampling techniques}

The researchers took a sample of the population (in table 1) because it is not possible to use the entire population of all students of all the higher institutions in Kogi State for the research, but rather we were more interested in seeking the opinion of those that will truly aid in information collection. In drawing the sample size for this research study, the researcher used the Taro Yamani (1967) formula cited in Israel (1992) as follows:

$$
n=\frac{N}{1+N(e)^{2}}
$$

Where:

$\mathrm{n}=$ Sample size desired;

$\mathrm{N}=$ Total Population $(10,370)$;

$1=$ Constant;

$\mathrm{e}=$ Level of significance $(0.05)$.

Using the formula above, the sample size is 385 . The breakdown is as follows in the number of copies of the questionnaire distributed in the six institutions, the Bowley (1976) proportional allocation formula was used:

$$
n_{1}=\frac{n(n h)}{N}
$$

Where:

$\mathrm{n}=$ Group population from each stratum; 
nh $=$ Overall sample size;

$\mathrm{N}=$ Overall population;

$\mathrm{n}_{1}=$ Sub-sample

The results are provided in Table 2 .

Table 2. Sub-sample frame

\begin{tabular}{|l|l|c|}
\hline S/N & \multicolumn{1}{|c|}{ Institutions } & Questionnaire distributed \\
\hline n1. & Kogi State University, Anyigba & 63 \\
\hline n2. & Federal College of Education Okene & 72 \\
\hline n3. & Federal Polytechnic Idah & 42 \\
\hline n4. & Federal University, Lokoja & 28 \\
\hline n5. & Kogi State Polytechnic, Lokoja. & 81 \\
\hline n6. & Kogi State College of Education, Ankpa & 99 \\
\hline & TOTAL & $\mathbf{3 8 5}$ \\
\hline
\end{tabular}

Source: Authors' Field Survey, 2020.

This study employed the multi-stage sampling technique which involved purposive sampling, stratified random sampling, and simple random sampling techniques. The first stage involved purposive sampling which was used to select the six (6) tertiary institutions such as; Kogi State University, Anyigba, Federal College of Education Okene, Federal Polytechnic Idah, Federal University, Lokoja, Kogi State Polytechnic, Lokoja, and Kogi State College of Education, Ankpa used for this study. The second stage involved the stratified sampling technique which was used to categorize the study population into six strata. Hence all students were grouped into male and female according to their institutions. This enhanced the identification of sub-groups within the study population and also created a sample that adequately represented these subgroups.

\section{Construct reliability and convergent validity}

Construct reliability was measured using composite reliability and Cronbach's Alpha. Convergent validity is often used to measure the correlation of a dimension's multiple indicators (Kothari \& Garg, 2014). Convergent validity in this pilot study was tested using Average Variance Extracted (AVE) as suggested by Garson (2016). The composite reliability coefficient should be $\geq 0.7$, Cronbach's Alpha coefficient should be $\geq 0.7$ (Hair et al. 2014) while the AVE coefficient should be $\geq 0.5$ (Garson, 2016). In Table 3, it can be seen that construct reliability and convergent validity have been achieved, as all composite reliability coefficients are above the threshold of 0.7 and all AVE coefficients are above the threshold of 0.5 .

Table 3. Pilot study: construct reliability and convergent validity

\begin{tabular}{lccc}
\hline \multicolumn{1}{c}{ Construct } & Items & CR & AVE \\
\hline Graduate unemployment & 5 & 0.86 & 0.52 \\
Entrepreneurial creative skill & 6 & 0.76 & 0.56 \\
Entrepreneurial teaching methods & 6 & 0.82 & 0.51 \\
Entrepreneurial risk-taking & 4 & 0.70 & 0.57 \\
Entrepreneurial career aspiration & 5 & 0.91 & 0.54 \\
Entrepreneurial culture & 6 & 0.73 & 0.61 \\
\hline
\end{tabular}

Source: Authors'compilation, 2020.

\section{Methods of data analysis}

In analyzing the data for this study, descriptive statistics and inferential statistics were used. The Descriptive statistics (Mean and standard deviation etc.) was used to describe respondents experience as relating to Entrepreneurial creative skill, teaching methods, risk-taking, career 
aspiration and culture in selected Kogi state tertiary institutions. The inferential statistics include the use of multiple regression analysis to estimate the impact of the independent variables (ECS, ETM, ERT, ECA, and ECL) on the dependent variable (GRU). The data collected underwent some processes using Statistics for Statistics Package for Social Science (SPSS) version 21.0 such as post- estimation tests before running the regression.

\section{Model specification}

Multiple Linear Regression Model (MLRM) was used to estimate the relationship between Entrepreneurial education and graduate unemployment in Kogi state tertiary institutions. Specifically, the regression model is:

The functional form of the relationship is provided in equation (3):

$$
Y=\beta_{0}+\beta_{1} E E_{i t}+\varepsilon_{t}
$$

Where $\mathrm{Y}$ is Graduate unemployment; $\mathrm{EE}_{\mathrm{it}}$ is a vector of Entrepreneurship Education and $\varepsilon_{\mathrm{t}}$ is the error term.

The model was modified to suit the best purpose of this research as shown in equation (4):

$$
G R U_{i t}=f(E C S, E T M, E R T, E C A, E C L)
$$

This model was further transformed into an econometric model as equation (5):

$$
G R U=\alpha+\beta_{1} E C S+\beta_{2} E T M+\beta_{3} E R T+\beta_{4} E C A+\beta_{5} E C L+\varepsilon
$$

Where:

$\mathrm{GRU}=$ Graduate Unemployment;

$E C S=$ Entrepreneurial Creative Skills;

$E T M=$ Entrepreneurial Teaching methods;

$E R T=$ Entrepreneurial Risk-taking;

$E C A=$ Entrepreneurial Career Aspiration;

$E C L=$ Entrepreneurial Culture;

$\alpha=$ Constant; $\beta 1, \beta 2, \beta 3, \beta 4$ and $\beta 5=$ Regression Coefficients; $\varepsilon=$ Error term.

\section{Data Presentation and Analysis}

Table 4. Summary of Response Rate

\begin{tabular}{lccc}
\multicolumn{1}{c}{ Item } & $\begin{array}{c}\text { No of } \\
\text { Copies }\end{array}$ & Returned & Rate \% \\
\hline $\begin{array}{l}\text { No of the questionnaire distributed to Kogi State University, } \\
\text { Anyigba }\end{array}$ & 63 & 62 & 16.1 \\
\hline $\begin{array}{l}\text { No of the questionnaire distributed to the Federal College of } \\
\text { Education, Okene }\end{array}$ & 72 & 69 & 17.9 \\
\hline No of a questionnaire distributed to Federal Polytechnic, Idah & 42 & 41 & 10.6 \\
\hline $\begin{array}{l}\text { No of the questionnaire distributed to Federal University, } \\
\text { Lokoja }\end{array}$ & 28 & 28 & 7.3 \\
\hline $\begin{array}{l}\text { No of the questionnaire distributed to Kogi State Polytechnic, } \\
\text { Lokoja }\end{array}$ & 81 & 80 & 20.8 \\
\hline $\begin{array}{l}\text { No of the questionnaire distributed to Kogi State College of } \\
\text { Education, Ankpa }\end{array}$ & 99 & 95 & 24.7 \\
\hline Total & $\mathbf{3 8 5}$ & $\mathbf{3 7 5}$ & $\mathbf{9 7 . 4}$ \\
\hline
\end{tabular}

Source: Researcher's computation from questionnaire distributed, 2020. 
Table 4 shows the summary of the number of questionnaires distributed and the number of questionnaires returned. A total number of 385 questionnaires were distributed to respondents. Kogi State College of Education, Ankpa were given the highest number of questionnaires with a figure of 99, having a return of 95. Kogi State Polytechnic, Lokoja were the next highest with 81 questionnaires distributed to them, having a return of 80. Next is the Federal College of Education, Okene, having 72 questionnaires distributed, with a return of 69. Also, 63 questionnaires were distributed to Kogi State University, Anyigba having a return of 62 . In Federal Polytechnic, Idah, a total of 42 questionnaires were distributed while 41 were returned according and lastly, in Federal University, Lokoja, a total of 28 questionnaires were distributed and returned. In total, 375 questionnaires were returned, constituting a 97.4\% response rate, which is suitable for further analysis.

Table 5. Demographic characteristics of respondents $(n=375)$

\begin{tabular}{|c|c|c|c|}
\hline Characteristics & & & \\
\hline Gender & Frequency & Percentage & Cumulative Percentage \\
\hline Male & 200 & 53.3 & 53.3 \\
\hline Female & 175 & 46.7 & 100. \\
\hline Total & 375 & 100 & \\
\hline Age Distribution & Frequency & Percentage & Cumulative Percentage \\
\hline $16-20$ & 45 & 12.0 & 12.0 \\
\hline $21-25$ & 158 & 42.1 & 54.1 \\
\hline $26-30$ & 98 & 26.1 & 80.2 \\
\hline $31-35$ & 74 & 19.8 & 100 \\
\hline Total & 375 & 100 & \\
\hline Marital Status & Frequency & Percentage & Cumulative Percentage \\
\hline Single & 281 & 74.9 & 74.9 \\
\hline Married & 94 & 25.1 & 100 \\
\hline Total & 375 & 100 & \\
\hline Tertiary institution type & Frequency & Percentage & Cumulative Percentage \\
\hline University & 90 & 24 & 24 \\
\hline Polytechnic & 121 & 32.3 & 56.3 \\
\hline College of Education & 164 & 43.7 & 100 \\
\hline Total & 375 & 100 & \\
\hline Ownership of Institution & Frequency & Percentage & Cumulative Percentage \\
\hline Federal & 138 & 36.8 & 36.8 \\
\hline State & 237 & 63.2 & 100 \\
\hline Total & 375 & 100 & \\
\hline Entrepreneurship Course contents & Frequency & Percentage & Cumulative Percentage \\
\hline The Institutions & 179 & 47.7 & 47.7 \\
\hline Government Agencies & 196 & 52.3 & 100 \\
\hline Total & 375 & 100 & \\
\hline
\end{tabular}

Source: Field Survey, 2020.

Table 5 presents the gender distribution of the sampled respondents. $53.3 \%$ of the sampled respondents were males while $46.7 \%$ of the respondents were females. This shows that males were more sampled than females. This signals that males are more concerned about 
entrepreneurship education and its impact on graduate unemployment in Kogi State tertiary institutions.

Also, from Table 5, it can be deduced that most of the sampled respondents of this study are either between the ages of $21-25$ and ages $26-30$, with $42.1 \%$ and $26.1 \%$ respectively. $12 \%$ of the respondents are between the ages of $16-20$ years, while $19.8 \%$ of the total respondents are 31-35 years. It is observed that most of the respondents are between ages 21 to 30 . This is as a result of the number of students in higher institutions in Kogi State who gained admission within the age brackets. Also, the table shows the Marital Status of the respondents, the analysis reveals that 281 respondents representing $74.9 \%$ are single, while 94 representing $25.1 \%$ of the respondents are married.

Also, the table revealed the University Type of the respondents, as it can be deduced, 90 representing $24 \% \%$ of the respondents are from universities, 121 respondents representing $32.3 \%$ are domiciled in the polytechnics while 164 respondents representing $43.7 \%$ are from colleges of education.

The table above equally shows the ownership of institution among the respondents, as it can be seen, 138 representing $36.8 \%$ of the respondents stated it is federal while, 237 respondents representing $63.2 \%$ are of the view of State government

Lastly, Table 5 also shows the contents of entrepreneurship education courses in Kogi state tertiary institutions. A significant proportion of sampled respondents obliged that its contents are from government agencies such as NUC, NBTE, and NCCE, taking a total of 52.3\%, while only $47.7 \%$ of respondents are from institutions.

Table 6. Descriptive statistics of variables

\begin{tabular}{lcccc}
\hline \multicolumn{1}{c}{ Variables } & Sample & Mean & Std. Deviation & T-statistics \\
\hline $\begin{array}{l}\text { Entrepreneurial creative } \\
\text { skills }\end{array}$ & 375 & 3.20 & 1.09 & 2.94 \\
$\begin{array}{l}\text { Entrepreneurial teaching } \\
\text { methods }\end{array}$ & 375 & 3.63 & 0.88 & 4.13 \\
$\begin{array}{l}\text { Entrepreneurial risk- } \\
\text { taking }\end{array}$ & 375 & 3.52 & 0.91 & 3.87 \\
$\begin{array}{l}\text { Entrepreneurial career } \\
\text { aspirations }\end{array}$ & 375 & 3.65 & 0.97 & 3.76 \\
Entrepreneurial culture & 375 & 2.14 & 1.07 & 2.00 \\
Graduate unemployment & 375 & 3.06 & 0.93 & 3.29 \\
\hline
\end{tabular}

Source: Field Survey, 2020.

Table 6 presents the descriptive statistics for Entrepreneurial creative skills, teaching methods, risk-taking, career aspiration, and culture. All constructs were measured using a five-point Likert scale. Table 6 showed a mean response of 3.20 on entrepreneurial creative skills, having a standard deviation of 1.09 with t-statistics of 2.94 . This is above average, which means the acquisition of creative skills needed by students of tertiary institutions will lower graduate unemployment in Nigeria.

Mean response of 3.63 on entrepreneurial teaching methods, the standard deviation of 0.88 , and t-statistics of 4.13show that respondents agreed that there is a significant relationship of teaching methods among students in lowering graduate unemployment in Kogi state tertiary institutions. Also, 3.52 mean response on entrepreneurial risk-taking with 0.91 standard deviation and $3.87 \mathrm{t}$-statistics shows that respondents are taught by entrepreneurship lecturers on how risk is a very paramount point while venturing into business. Also, a mean response of 3.65 on entrepreneurial career aspiration means tailoring entrepreneurial skills in Nigerian tertiary institutions needs to be aligned with the course content to meet up to curbing unemployment in 
the country. Lastly, entrepreneurial culture exhibits a mean response of 3.06 with a standard deviation of 0.93 and t-statistics of 3.29. This means that lecturers in the institutions need functional projectors, textbooks, and spacious lecture rooms for effective teaching in the class. This will help students to imbibe entrepreneurial culture.

Table 7. Regression result showing entrepreneurship education and graduate unemployment

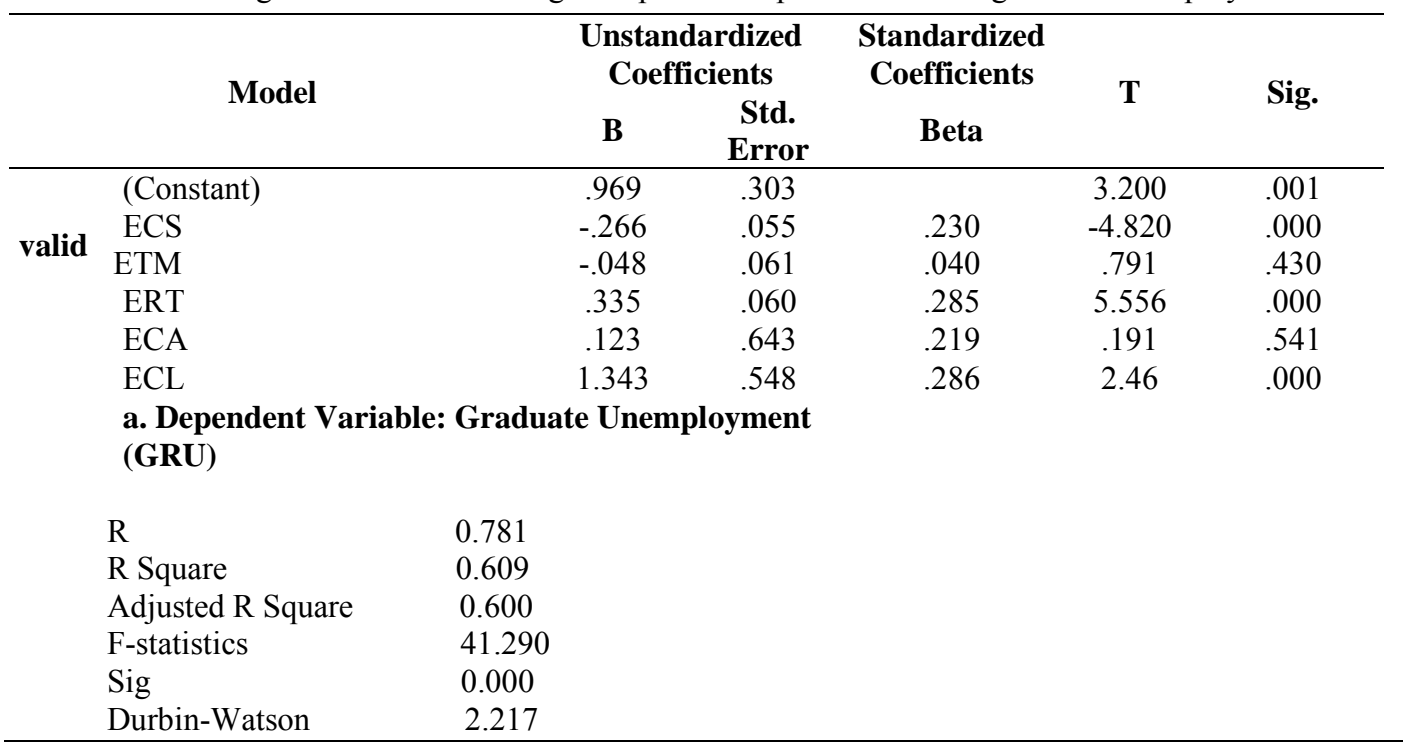

Source: Field Survey, 2020.

The regression results table above, reports the multiple linear correlation coefficient $(\mathrm{R})$, the coefficients of determination $\left(\mathrm{R}^{2}\right)$, the variance (Adjusted $\mathrm{R}^{2}$ ), and the Durbin-Watson Statistics. The regression value of 0.781 indicates that there is a strong relationship between the dependent and the joint independent variables. The $\mathrm{R}^{2}$ value of 0.609 shows that changes in entrepreneurship education are explained or captured by the estimated model to the tune of about $60.9 \%$ to Graduate unemployment in Nigerian tertiary institutions. Meanwhile, after accounting for the number of regressors included in the model estimated, variation in the dependent variable is jointly accounted for by the independent variables to the tune of $61 \%$.

A negative linear relationship exist between Entrepreneurial Creative Skills and graduate unemployment (give that $\beta=-0.266$; $p$-value $=0.01$ ). This assumes that increasing acquisition of Entrepreneurial Creative Skills will lead to decreasing graduate unemployment. Entrepreneurial Teaching Methods has insignificant negative linear relationship with graduate unemployment (give that $\beta=-0.048 ; p$-value $>0.05$ ). That is improvement on the Entrepreneurial Teaching Methods will not significantly reduce graduate unemployment. A positive linear relationship exist between Entrepreneurial Risk-Taking and graduate unemployment (give that $\beta=0.335$; $p$ value $=0.01$ ). The assumption of this is that Entrepreneurial Risk-Taking is not scientifically inclined, and may have been taken in the wrong direction. Graduate unemployment increases concomitantly with the increase in Entrepreneurial Career Aspiration (give that $\beta=.123$; pvalue $>0.05$ ). The positive linear relationship appears to be insignificant. The linear relationship between Entrepreneurial Culture and graduate unemployment in Kogi State is positive (give that $\beta=1.343 ; p$-value $=0.01$ ). The assumption follows that the increase in Entrepreneurial Culture with a corresponding increase in graduate unemployment in Kogi State is an indication of poor Entrepreneurial Culture. The t-statistics show that the residuals are normally distributed (Appendix 1). The independent variables (such as Entrepreneurial Creative Skills, Entrepreneurial Teaching methods, Entrepreneurial Risk-taking, Entrepreneurial Career Aspiration, and Entrepreneurial Culture) did not correlate highly with each other (Appendix 2). 
The Durbin- Watson value reported in the regression table above indicates whether or not there is a presence of autocorrelation in the error term of the estimated model. According to Norusis (1999), Durbin- Watson's value between "1.50 - 2.50" indicates the absence of autocorrelation. Since the Durbin -Watson value reported in the regression result is 2.217 (which is greater than the Durbin-Watson critical value of 1.639), it can be concluded that there is the absence of autocorrelation in the error term of the model, signifying that the model can be used for predicting the entrepreneurship education in selected universities in Kogi State. The negative skewness and kurtosis for the items of each of the investigated variable suggests that the data did comply with the symmetrical distribution assumption (Appendix 3).

The F-Statistics value presented in the regression results table above allows an evaluation of the statistical significance of the estimated model. Based on the F- statistics criterion and its associated sig. value, using these statistics, $(\mathrm{F}=41.290, \mathrm{Sig}=.000(\mathrm{P}<0.01))$, the estimated model significantly explained variation in entrepreneurship education. This implies that the model has a good fit.

\section{Discussion of Findings}

Review of extant literature revealed that entrepreneurship education is an educational strategy mostly targeted at curbing graduate unemployment by motivating students 'entrepreneurial intentions and skill as well as the creation of successful businesses by graduates of higher institutions in Kogi State. Hence, entrepreneurship education for the creation of successful businesses is regarded as the popular teaching goal. Therefore various aspects of entrepreneurship education such as; creative skills, teaching methods, risk- taking, career aspirations and culture among higher institutions environment in Kogi State may have implications for graduate unemployment in Nigeria. These elements were thoroughly analyzed accordingly.

The regression result exhibits a positive and significant impact of entrepreneurial risk- taking on graduate unemployment in Kogi state tertiary institutions. This is in line with the work of Ezeanokwasa and Nwanchukwu (2014) who are of the view that effective entrepreneurial risk taking knowledge among students of higher institutions would curb gradate unemployment in the society.

Findings revealed from the descriptive statistics (mean, standard deviation and t-statistics) that most of the respondents was positive about how career aspiration in venturing to entrepreneurship will curb unemployment in the country. This was also validated by the result of the empirical findings of this research which revealed that various aspects of an entrepreneurship programme inculcate various entrepreneurial abilities in learners and motivate entrepreneurial development of students. The result of the analysis of entrepreneurship education relative to course contents revealed that entrepreneurship education curriculum contents in the various institutions are appropriate to equip the students with entrepreneurial competencies and skills to enable them to become self-reliant and to participate effectively in the world of work but the time allotted to deliver the course content effectively appears to be grossly inadequate which constitutes one of the major constraints to the realization of the course objective. Also, the regression result show that there exists a positive and significant impact of entrepreneurial career aspiration and graduate unemployment in Kogi state tertiary institutions.

Findings from Hypothesis five, it was revealed from the descriptive statistics (mean, standard deviation and t-statistics) that most of the respondents stated that entrepreneurial culture has a significant relationship with graduate unemployment in Kogi state tertiary institutions. The findings from the descriptive statistics also showed that most respondents agreed that there is a commonality of purpose and interest among entrepreneurship students. Furthermore, findings 
from the descriptive statistics indicated that most respondents agreed that the entrepreneurship culture has enhanced students to create new business processes.

This shows that the adoption of practical activities considered as best practices in entrepreneurship culture can facilitate business start-ups by stimulating students 'interest with active real-world activities. This is in line with the work of Favour, (2012) who recommended that the appropriate cultural methods for entrepreneurship education include practical activities such as; group project, case study, individual project, venture creation project, and problemsolving. This also extends the results of the study of Jones (2012) which indicated that the development of appropriate culture methods has implications for student's business startup. Although, the findings of some studies such as Wisdom1 (2004), supported by Hannah, (2015) suggests that participation in an entrepreneurship programme is averse to the development of students 'interests and business startup potentials. This study counters this stance based on the findings from this research which suggests that using the appropriate cultural methods and best practices in entrepreneurship culture, may motivate students 'interest for business startups in the course of the programme. Also, the regression result shows that entrepreneurial culture has a positive and significant relationship with graduate unemployment in Kogi state tertiary institutions.

\section{Conclusion}

This study has shown that the contents of the curriculum for entrepreneurship programmes in the selected higher institutions in the Kogi State of Nigeria, enhance the development of novel and creative business ideas by stimulating critical thinking in students. However, there is still a challenge on what should be defined as practical activities in entrepreneurship education, as most practical activities tend towards the acquisition of vocational skills, rather than the development of entrepreneurial skills and aptitudes. There is also clear evidence to validate that experiential pedagogical approach adopted in the selected institutions in Kogi State, motivate identification of business opportunities by experientially creating a shared vision of the process of entrepreneurship. Nevertheless, there are indications that the class sessions are monotonous, and may not stimulate students 'interest and focus towards the theoretical knowledge of the curriculum.

This study provides valid evidence to show that the adoption of effective teaching methods in entrepreneurship facilitates in curbing graduate unemployment in Kogi State and Nigeria at large. This study concludes that the experience and skill of entrepreneurship educators in the selected higher institutions in Kogi State motivate students to write business plans. Nevertheless, some of the educators 'lack of training on modern approaches for the effective delivery of entrepreneurship courses. Another inference of this study is that support systems in Nigerian universities relevant to entrepreneurial development such as entrepreneurship mentoring, seed funding, business incubation, among others, create a suitable environment for innovations. However, these initiatives are not introduced early enough to students, which may impede their abilities to develop business initiatives.

\section{Recommendations}

These recommendations stemmed from the findings of this study.

1. The regulatory authorities should ensure that lecturers comply with Entrepreneurial education policies for a more effective outcome of the programme in Kogi State higher institutions.

2. Lecturers should not limit themselves to using the orthodox lecture method in delivering the course content, rather they should make a paradigm shift and use other teaching 
methods and strategies for effective teaching in Kogi State higher institutions and Nigeria at large.

3. Entrepreneurial risk- taking should be taught among students of higher learning.

4. The different government agencies and the tertiary institutions authorities should ensure that adequate entrepreneurial career opportunity is provided to enable students' aspiration in Kogi State higher institutions.

5. The government should ensure adequate provision of material resources that could facilitate effective teaching/learning of the course considering its importance to addressing the unemployment challenges facing young tertiary school graduates.

\section{References}

1. Adiak, M. W., \& Katura, J. I. (2014). Entrepreneurial Education at the Tertiary Level in NigeriaImperative for Poverty Reduction and Economic Development.

2. Afolabi, F. Y. M., \& Idowu, E. (2014). Ameliorating the problems of unemployment among graduates through relevant functional and sustainable university education in Nigeria. International Review of Social Sciences and Humanities, 7(2), 188-196.

3. Ayo-Balogun, A. O. (2016). Entrepreneurship Education as a strategy for repositioning Technological education in Nigeria.

4. Bakar, R., Islam, M. A., \& Lee, J. (2015). Entrepreneurship Education: Experiences in Selected Countries. International Education Studies, 8(1), 88-99.

5. Elmuti, D., Khoury, G., \& Omran, O. (2012). Does Entrepreneurship Education have a role in developing Entrepreneurial Skills and Ventures Effectiveness: Journal of Entrepreneurship Education, 15, 83.

6. Eneji, M., Mai-Laifa, D., \& Wiping, S. (2013). Socio-Economic Impact of Graduate Unemployment in Nigeria and the Vision 2020. International Journal of Development and Sustainability, 2(1), 148178.

7. Federal Republic of Nigeria (FRN, 2016).National Policy on education. Lagos: NERDC press. Hagen, E. E. (2013). On the theory of social change: How economic growth begins. Illinois: Dorsey press. 5(16)18, 20-25.

8. GEM Global Entrepreneurship Monitor. (2019). Empreendedorismo no Brasil, Relatrio Executivo

9. Hair, J., Black, W., Babin, B., \& Anderson, R. (2014). Multivariate data analysis (7th ed.). UK: Pearson New International Edition.

10. International Labour Organization (ILO, 2017) Global. Employment trends, www.ioorg/wcmsp5/group/public.../cwcms150440. Retrieved: October20, 2011.

11. Israel, G. D. (1992). Determining sample size.

12. Jones, P., Pickernell, D., Fisher, R., \& Netana, C. (2017). A tale of two universities: graduates perceived value of entrepreneurship education. Education+ Training.

13. Kothari, C. R., \& Garg, G. (2014). Research Methodolgy; Methods and Techniques (3rd ed.). New Delhi: New Age International Limited.

14. Longe, O. (2017). Graduate unemployment in Nigeria: causes, consequences and remediable approaches. American International Journal of Contemporary Research, 7(4), 63-73.

15. National Directorate of Employment (NDE, 2015) Report on the registration of unemployment persons. Planning, research and statistics. Abuja: NDE. 9(12)16-17.

16. Norusis, M. J. (1999). SPSS for Windows (Version 10.0). Chicago, IL, SPSS Inc.

17. Nwachukwu, I (2013) Nigeria's unemployment rate at $23.9 \%$ in $2011 . \mathrm{http} / /$ business day on line.com/NG/index.phb/economic. Watch/32204 ...) Retrieved on 20/08/14

18. Ogwu, E. N., Omeje, M. O., \& Nwokenna, E. N. (2014). Structural Curriculum Reform and Unemployment among Youths in Nigeria: Implications for Peace and Development. International Journal of Humanities, Social Sciences and Education, 1, 44-50.

19. Okoye N. C., Iloanya, K. \& Udunze, U. (2014). Youth unemployment and entrepreneurship development: Challenges \& prospects in Nigeria. Kuwait Chapter of Arabian. Journal of Business and Management Review.

20. Salihu, A.J., (2014) Impact of Motivation on Employees Retention in Nigeria Deposit Money Banks, Abuja Metropolis: Being an M.Sc dissertation at the Department of Business Administration,Nasarawa State University Keffi. 45-48. 
21. Sania, A., \& Jamilb, H. (2020). Entrepreneurship Programs in Nigeria: Indicators for Graduates Employability. Education, 12(8).

22. Yamane, T. (1967). Statistics: An Introductory Analysis Analysis (No. HA29 Y2 1967).

Appendix 1. Correlation matrix

\begin{tabular}{|l|cccccc|}
\hline & GRU & ECS & ETM & ERT & ECA & ECL \\
\hline GRU & 1.0000 & & & & & \\
ECS & 0.2952 & 1.0000 & & & & \\
ETM & -0.0938 & 0.1575 & 1.0000 & & & \\
ERT & -0.0435 & -0.2585 & 0.1338 & 1.0000 & & \\
ECA & 0.1348 & 0.3705 & 0.1354 & 0.3961 & 1.0000 & \\
ECL & -0.0682 & 0.1750 & -0.0184 & -0.4371 & -0.4400 & 1.0000 \\
\hline
\end{tabular}

Appendix 2. Multicollinearity test

\begin{tabular}{|l|c|c|}
\hline \multicolumn{1}{|c|}{ Construct } & VIF & Tolerance value \\
\hline Entrepreneurial creative skills & 1.111 & 0.900 \\
\hline Entrepreneurial teaching methods & 1.281 & 0.781 \\
\hline Entrepreneurial Risk-taking & 1.283 & 0.779 \\
\hline Entrepreneurial career aspirations & 3.326 & 0.764 \\
\hline Entrepreneurial culture & 1.007 & 0.993 \\
\hline
\end{tabular}

Appendix 3. Normality test

\begin{tabular}{|c|c|c|c|c|c|}
\hline Construct & Items & Skewness & $\begin{array}{l}\text { Skewness } \\
\text { Std. Error }\end{array}$ & Kurtosis & $\begin{array}{l}\text { Kurtosis Std. } \\
\text { Error }\end{array}$ \\
\hline \multirow{5}{*}{$\begin{array}{l}\text { Graduate } \\
\text { unemployment }\end{array}$} & GRU1 & -0.18 & 0.12 & -0.91 & 0.24 \\
\hline & GRU2 & -0.58 & 0.12 & -0.19 & 0.24 \\
\hline & GRU3 & -0.14 & 0.12 & -0.77 & 0.24 \\
\hline & GRU4 & -0.64 & 0.12 & -0.65 & 0.24 \\
\hline & GRU5 & -0.17 & 0.12 & -0.72 & 0.24 \\
\hline \multirow{6}{*}{$\begin{array}{l}\text { Entrepreneurial } \\
\text { creative skills }\end{array}$} & ECS1 & -0.87 & 0.12 & 0.22 & 0.24 \\
\hline & ECS2 & -0.57 & 0.12 & -0.18 & 0.24 \\
\hline & ECS3 & -0.58 & 0.12 & -0.17 & 0.24 \\
\hline & ECS4 & -0.61 & 0.12 & -0.17 & 0.24 \\
\hline & ECS5 & -0.55 & 0.12 & -0.15 & 0.24 \\
\hline & ECS6 & -0.51 & 0.12 & -0.16 & 0.24 \\
\hline \multirow{6}{*}{$\begin{array}{l}\text { Entrepreneurial } \\
\text { teaching methods }\end{array}$} & ETM1 & -0.80 & 0.12 & 0.10 & 0.24 \\
\hline & ETM2 & -0.63 & 0.12 & -0.22 & 0.24 \\
\hline & ETM3 & -0.69 & 0.12 & 0.03 & 0.24 \\
\hline & ETM4 & -0.66 & 0.12 & 0.05 & 0.24 \\
\hline & ETM5 & -0.61 & 0.12 & 0.06 & 0.24 \\
\hline & ETM6 & -0.64 & 0.12 & 0.07 & 0.24 \\
\hline \multirow{4}{*}{$\begin{array}{l}\text { Entrepreneurial risk- } \\
\text { taking }\end{array}$} & ERT1 & -0.85 & 0.12 & 0.84 & 0.24 \\
\hline & ERT2 & -0.54 & 0.12 & 0.36 & 0.24 \\
\hline & ERT3 & -0.27 & 0.12 & 0.67 & 0.24 \\
\hline & ERT4 & -0.24 & 0.12 & 0.54 & 0.24 \\
\hline \multirow{5}{*}{$\begin{array}{l}\text { Entrepreneurial career } \\
\text { aspirations }\end{array}$} & ECA1 & -0.68 & 0.12 & 0.57 & 0.24 \\
\hline & ECA2 & -0.72 & 0.12 & 0.51 & 0.24 \\
\hline & ECA3 & -0.77 & 0.12 & 0.46 & 0.24 \\
\hline & ECA4 & -0.61 & 0.12 & 0.48 & 0.24 \\
\hline & ECA5 & -0.69 & 0.12 & 0.51 & 0.24 \\
\hline \multirow{6}{*}{ Entrepreneurial culture } & ECL1 & -0.88 & 0.12 & 0.32 & 0.24 \\
\hline & ECL2 & -0.58 & 0.12 & 0.05 & 0.24 \\
\hline & ECL3 & -0.65 & 0.12 & 0.07 & 0.24 \\
\hline & ECL4 & -0.71 & 0.12 & 0.03 & 0.24 \\
\hline & ECL5 & -0.66 & 0.12 & 0.15 & 0.24 \\
\hline & ECL6 & -0.64 & 0.12 & 0.10 & 0.24 \\
\hline
\end{tabular}

